Jap. J. Limnol. 41, 4, 225-234, 1980.

\title{
富栄養河川における付着微生物群集の発達にともなう 現存量および光合成量の変化
}

\author{
相 崎 守 弘 \\ Changes in Standing Crop and Photosynthetic Rate attendant on the \\ Film Development of Periphyton in a Shallow Eutrophic River.
}

\author{
Morihiro AIzAKI
}

\begin{abstract}
Microbial succession and changes in photosynthetic rate attendant on the film development of periphyton were investigated using artificial substrata in a shallow eutrophic region of the midstream of the Tamagawa River. Bacteria played the role of pioneer colonizer in the periphyton development. Algae joined the community after formation of bacterial colonies on substrata and dominated in the mature stage. Algae accounted for about 80 percent of the periphyton community in maximum and 50-70 percent in carbon weight under ordinary conditions in spring. Total numbers of aerobic heterotrophic bacteria were $10^{7}-10^{9}$ cells $/ \mathrm{cm}^{2}$ and $10^{10}-10^{12}$ cells $/ \mathrm{gC}$ in the mature stage. A number of sulfate-reducing bacteria were also found in that stage. Photosynthetic rates of sessile algae varied widely with film development of periphyton. They showed $3-20 \mathrm{mg} \cdot \mathrm{O}_{2} / \mathrm{mg} \cdot \mathrm{chl}$. $-\mathrm{a} \cdot \mathrm{hr}$ in the early stage and 1-3 $\mathrm{mg} \cdot \mathrm{O}_{2} / \mathrm{mg} \cdot \mathrm{chl}-\mathrm{a} \cdot \mathrm{hr}$ in the mature stage. An extremely low photosynthetic rate was found just before the exfoliation of periphyton occurred.
\end{abstract}

\section{1. はじめに}

付着微生物群集は，湖沼や河川の沿岸帯や河床にお ける生産者および分解者として重要な位置を占めてい る. 特に浅く流れの速! 河川では, 石楅上の付着微生 物群集が有機物の生産および分解のほとんどを担って いる，付着微生物群集はその中生産者である藻類, 分解者である細菌類，および消費者である原生動物類 や比較的大型な水棲屁虫類をも念むへテロな系であり， 厚さわずか数ミリの膜内に 1 つ生態系が欵縮されて いる．このような付着微生物群集は，富栄美化した河 川では非常に短期間で增殖と剥離をくりかえしており (AIZAKI，1978)，また群集を構成している細菌類や藻 類の增殖速度も非常に速い( АIZAKI，1979). そのた め, その現学量や代謝活性は常に変化しており，一定 のものとしてはとらえられない.てのような変化は付 着微生物群集の增殖によって微生物膜が次第に厚くな り，膜内部の環境条件か変わるために引き起てされる ものと考えられる. したがって, 测川における付着微
生物群集の現存量や機能を知るためには，微生物膜の 発達にともなうこれらの変化を知る必要がある。本研 究では，てのような短期間での変化を明らかにするた めに, 日本の代表的富栄養河川である多摩川中流部に おいて，人工基層をもちい，付着微生物量および光合 成速度の付着膜形成にともなう変化を測定した。

本研究を行なうにあたっては東京都立大学手塚泰彦 博士, 林秀剛氏, 滛井進博士, 西野泰子氏らをはじめ とする多くの方がたから助言，協力をいただいた，乙 こに記して感謝の意を表する。

\section{2. 調查地点および方法}

多摩川は東京都の南西部を流れる長さ約 $100 \mathrm{~km}$, 流域面積約 $1,200 \mathrm{~km}^{2}$ の河川である。近年, 流域の 開発により多量の都市廃水が流入するようになり, 污 濁の著しい河川として知られるようになった（古井戸 . 土屋, 1970 ; 土屋他, 1970; TEZUKA et al., 1974). 調查はこのような多摩川の中流部で行なった。 調查 地点は丸子橋の上流約 $2 \mathrm{~km}$ の地点で, 巾約 $100 \mathrm{~m}$, 
深さ約 $30 \mathrm{~cm}$, 流速 $0.6 \sim 1.0 \mathrm{~m} /$ 秒程度の浅瀬である. 河床は直径 $10 \sim 20 \mathrm{~cm}$ 程度の石䃯であった。調査は 1972 年から 1974 年にかけて行なったが, その間の水 質は前報（AIZAKI，1978，1979）を参㬎されたい。

実験は主に塩化ビニール製の板およびスライドグラ スを使用して行なった，塩化ビニール板は $5 \mathrm{~cm} \times$ $5 \mathrm{~cm}$ のものを用い，測定呮差を少なくするために 表面をやすりで処理し，表面粗度を増加させた。乙れ らの基首を鉄製のアングルに圆定し，面が流れに対し て平行でほぼ水平になるように水中へ沈めた，1回の 実験には 10〜20 枚のスライドグラスと 15〜30枚の塩 化ビニール板を使用した。 これらの基序は $2 \sim 4$ 日の 間隔で採取し，ぬれた状態を保って実験室へ持ち臣っ た. スライドグラスは顕微鏡観察, 塩化ビニール板は 付着微生物現存量および光合成量の測定用の試料とし た. 現存量および光合成量の測定方法の詳細は前報 (АІzакI，1978) に記載したので簡単に述べる。付亶 物は塩化ビニール板から㕷ぎ落とし，一起量の純水に 懸濁させ，その一部をグラスファイバーフィルター（ ミリポア社, AP 20) でろ過後, 乾燥重量, 炭素量お よびクロロフィル量の测定試料とした。乾燥重量は

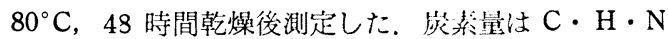
コーダ (柳本社) で測定し，炭䋕望の 2 倍を有機物量 とした. クロロフィル量は UNESCO/SCOR 法で测 定した。また，懸濁した付着物の一部は $20 \mathrm{kc} の$ 超省 波粉砕機（梅田電気社）で 30 秒間処理し， 細菌数計 数用の試料とした．全従属栄盖細菌数は桜井培地（桜

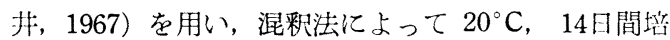
養後に計数した，硫酸塩還元細菌数は河合（1969）に 準じて MPN 法で測定した。光合成速度は付着物が 塩化ビニール板に付着したままの状態で, 特製の容器

$(9 \mathrm{~cm} \times 5.3 \mathrm{~cm} \times 4 \mathrm{~cm})$ 亿入れ，付着物と同時 に採取してきた河川水を満たし，現場水温に保ちなが ら 500 ワットの電球で光照射し, スターラーで靦挥し ながら容器内の溶存酸素量の変化を浴存酸素計（東芝 ベックマン社）で測定して求めた.

\section{3. 結 果}

\section{1. 顕微鏡観察}

付着微生物膜の形成過程を調べるために顕微鏡によ る観察を行なった，浸漬したスライドグラスにまず初 めに付着したのは，各季節に数回行なった観察では， 常に細菌類であった。これらの細菌類のうち，付着㬝 形成の初期に增殖してコロニーを形成する細菌が付着 膜形成に重要な役割を果たしているように思われた

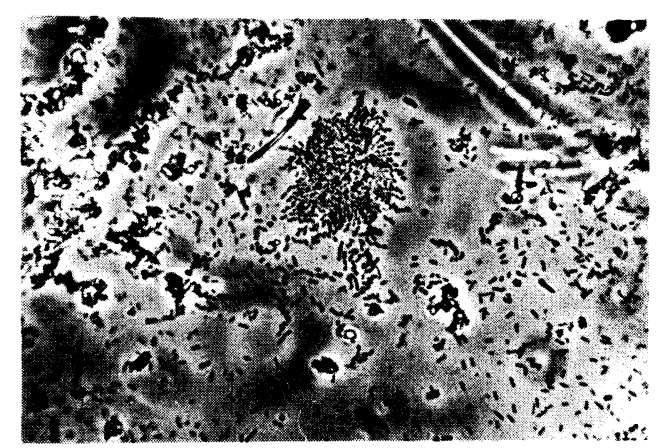

Fig. 1. Early stage of periphyton development in the midstream of the River Tamagawa. Microcolonies of bacteria were found on a microscopic slide glass. The slide was submerged for 7 days in river water in spring. $(\times 200)$.

(Fig. 1). Sphaerotilus sp.のような糸状の細菌も 同時に付住し，後期における厚い付社膜の形成を担う 役割を啉たした。

細藏類がある程度付神すると测川小中のデトリタス もトラッフされるようになり, 付着膜の形成を促進し た。形成された細菌膜は基四表面の流速を弱めるため か, 次に運動性のある繊毛虫類や理澡類が現れること が多かった，特に珪澡は紐菌のコロニーに体を突っ込 むような形で増殖しているてとが多かった（Fig. 2.）

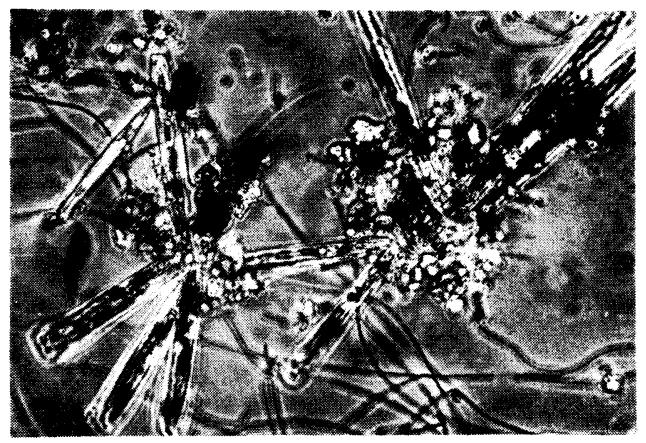

Fig. 2. Mid-stage of periphyton development in the midstream of the River Tamagawa. Algae joined the community. The slide was submerged for 18 days in river water in spring. (phase contrast, $\times 1000)$.

紐菌膜が形成されると, Vorticella sp.や Epistylis sp.のような国着性の原生動物もかなり增殖してきた。 また, Stigeoclonium sp. や Gomphonema sp. のよ うな固着性の藻類もこのころより增加し始め, 最終的 にはStigeoclonium sp. が優与種になることが多か 


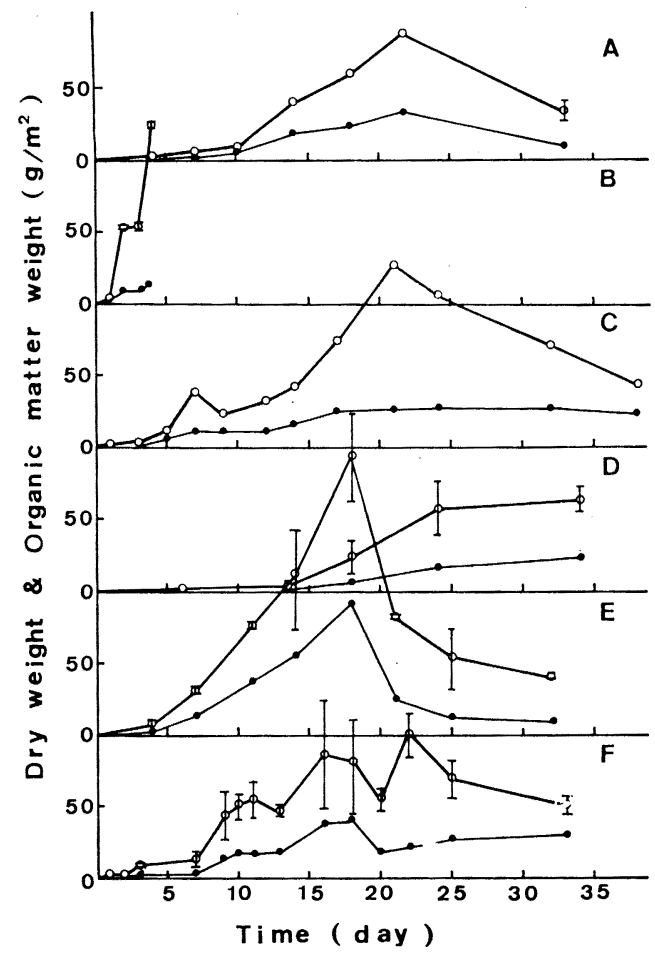

Fig. 3. Changes of dry weight and organic matter attendant on film development of periphyton in the midstream of the River Tamagawa. A, Mar. 1972: B, Aug. 1972. The experiment was stopped halfway due to the riparian work near the station. C, Oct. 1972; D, Jan. 1973; E, May 1973; F, Jul. 1973. Symbols: -O-, dry weight; ---, organic matter content.

った. ネマトーダや Chironomidae の拗虫といった 小型動物は首がかなり厚くなってから現れた。

\section{2. 現存量の変化}

A. 乾燥重量わよび有機物含量

層形成に伴う付着物量の変化を調べるために, 1972 年春から 1973 年夏にかけて数回実験を行なった。結 果を Fig. 3 亿示す. 付着物の増加の様子は各季節 と も似通っていたが，現存量が急激に増加し始めるのに 要する日数, 最高值に達するまでの日数, および現存 量の最高值等に違いが見られた。図から明らかな如く， 付着物量は最高值に達した後, 急激な減少を示した。 てれは付着物の剶離によるものである。このため, 微 生物の成長曲線にみられる遅滞期, 刘数增殖期, 静止 期, 死滅期のうち Fig. 3 の増加曲線には後の 2 つの 期間, 静止期, 死㓕期が見られなかった。すすなわち, 污
淘河川の付着微生物群集は対数增殖期のすぐ後に剥離 するというサイクルを繰り返しているととがわかった。

てのような增殖および剥離の 1 サイクルに要する日 数は春季および秋季では約 1 力月, 夏季では約 2 週間, 冬季では約40日以上であった，付着物乾燥重量は春季 に最も高くなる傾向があり, 得られた最高值は約 190 $\mathrm{g}$ dry wt. $/ \mathrm{m}^{2}$ であった。 この值は, 藻類の増殖に最 適な 5 月に行なった実験で得られた。他の季節では 約 80 130 g dry wt./m² 程度まで增加後剝離した。 現存量の測定は 1 枚ないし 2 枚の付着板を使用して行 なったが，板ごとの違いは層形成の初期および剥離後 ではあまり大きくなかった，しかし，現存量が最高值 に近くなり，厚い付着物膜を形成している時にはかな りの違いが見られた。このような違いは付着物の一部 の剥離によるものと思われた。

付着物中の有機物含量には各季節とも大きな変化は 見られず，約 30〜40\% を示した。 ただし，Fig. 3-B の実験では，実験期間中に上流で土木工事が始まり， その影響で無機物量が増加した。このような測定結果 から付着物重量の半分以上は無機物であるととがわか ったが，乙れらは比重がかなり大きいため，体積的に は付着物層のほとんどが有機物，すなわち，付着性微 生物によって占められていた。 Fig. 3 から計算され た付着微生物群集の増加速度は, 炭素量に換算して, 夏季では約 $2 \mathrm{~g} \cdot \mathrm{C} / \mathrm{m}^{2} \cdot \mathrm{day}$, その他の季節では約 $1 \mathrm{~g}$ $\mathrm{C} / \mathrm{m}^{2}$ •day 程度であった。しかし，最も增殖に適した 条件が与えられた場合には，Fig. 3-E とみられるよ うに, 約 $3 \mathrm{~g} \cdot \mathrm{C} / \mathrm{m}^{2} \cdot$ day という非常に大きな值を示 した.

B. 藻類量

Fig. 4 亿付着微生物膜の形成に伴うクロロフィル a 量の増加曲線を示す. 図から明らかな如く, 藻類が 急激に増殖し始めるまでにかなり長い遅滞期が存在し た。 この遅㴖期の長さは水温と密接な関係が見られた (Fig. 5)。顕微鏡観察では， ある程度の細菌膜が基 首上に形成された後に藻類の増加が見られたととから， この遅滞期間は基層上に細菌膜を形成するのに要する 時間と思われた。すすなわち, 細菌や藻類の増殖速度と 水温の間に高い相関関係が見られるととから（AIZAKI， 1979), 冬季では長い遅滞期間を必要とし, 夏季には 短い遅滞期間で澡類が増殖するものと思われた。おお まかな計算ではての遅滞期間は細菌の約 18２0 回の 分裂に要する時間と一致した。

クロロフィル a の増加曲線は, 乾燥重量の堨合之同 様に, 通常の成長曲線に見られる静止期, 死滅期を欠 


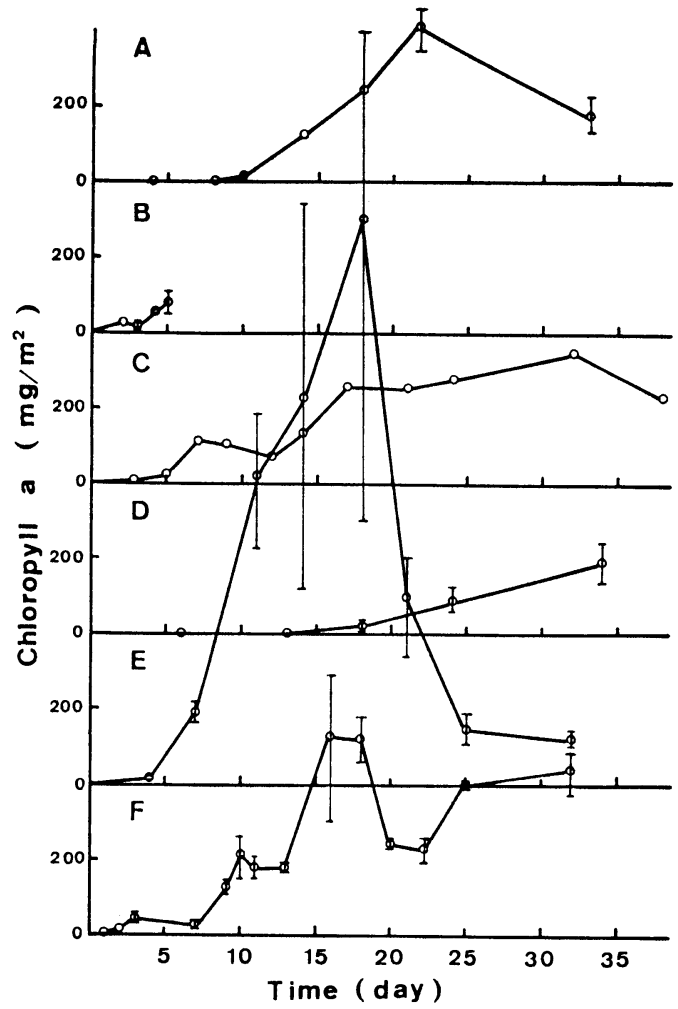

Fig. 4. Changes of chlorophyll-a amount attendant on film development of periphyton in the midstream of the River Tamagawa. A, Mar. 1972; B, Aug. 1972. The experiment was stopped halfway due to the riparian work near the station. C, Oct. 1972; D, Jan. 1973; E, May 1973; F, Jul. 1973.

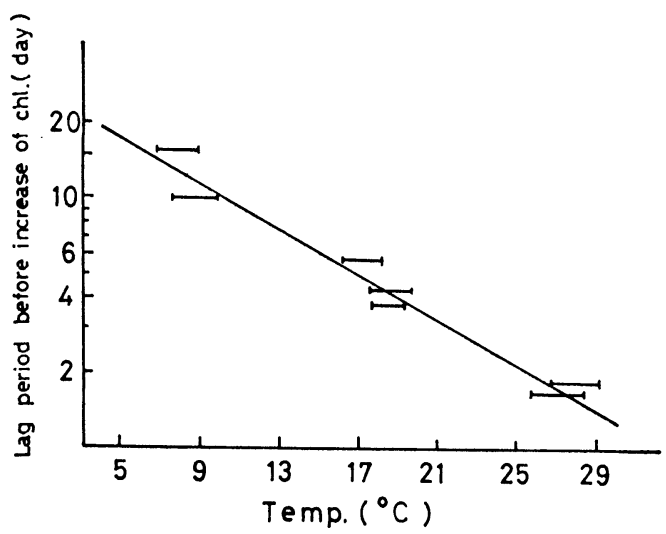

Fig. 5. Relationship between the water temperature and the length of lag periods before the rapid increase of chlorophyll in periphyton occurred.
き, 現存量が最高値に達した後, 剝離によって急激に 減少した. この堌加曲線は Fig. 3 亿示した付着物中 の有機物含量の曲線と良い一致を示した。このことは， 付着微生物群集中に占める澡類の割合が非常に滈いこ とを亦すものと考えられた，クロロフィルa量の最高 值は季節によってかなり巽なるが約 400〜500 mg・ $\mathrm{chl} . \mathrm{a} / \mathrm{m}^{2}$ 程度の值が多かった. しかし, 条件さえ整え ば，Fig. 4-E に見る加く， 約 $1,500 \mathrm{mg} \cdot \mathrm{chl} . \mathrm{a} / \mathrm{m}^{2}$ という非常に高、值を示す場合もあった。

以上の如く，付省物中に多量の澡類の存在が明らか になったので, 次に付着物中の澡類の㓶合および, こ れの着形成に伴う変化を検討してみた．前述した如く， 付着微生物群集中には澡類の他に多量の細菌や原生動 物, デトリタス等を含むことから, 澡類だけの量を求 めるには多少の工夫が必要である。乙てでは, クロロ フィル a の濃度を炭系量に換算するという方法で付着 物中の澡類量の割合を算出した，藻体中のクロロフィ ル a 含量は栄養状態や光条件などにより変化するので (STEELE and BAIRD，1962，1965)，夹験的にその換 算係数を求めた。すなわち，従属栄養的な微生物群集

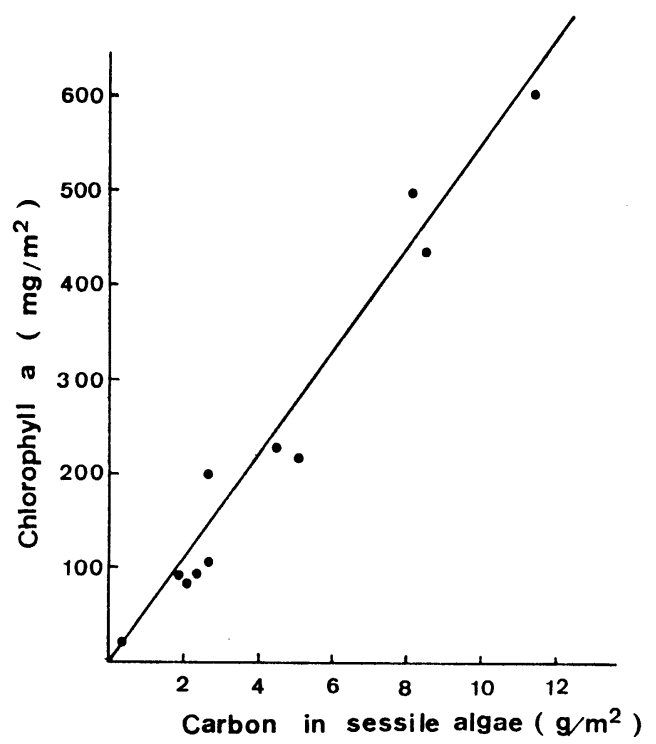

Fig. 6. Relationship between carbon and chlorophyll-a amount of sessile algae in spring. Carbon amount of sessile algae was determined by subtracting carbon weight on the reverse surface from that on the obverse surface of the substratum. The periphyton community on the reverse surface was almost entirely constituted by heterotrophic microorganisms. 
の現存量は付着板の裏面と暗状態汇保った付着板表面 とで，圈形成初期ではあまり違いがなかったてとから (相崎, 未発表), 層形成初期の付着板表面の付着物 炭点量汃付着板塞面の付着物炭素量を差し引くこと によって澡類の炭素量を求め, その值とクロロフィル $\mathrm{a}$ 量との関係から単位クロロフィル量当りの炭素量を 求めた。 その結果を Fig. 6 亿示す.

なお, こてで用いた值は, 藻体中のクロロフィル a 含量の季節的変化を考虑して春季に得られた值のみ使 用した。この絬果，雨者の間に高い相関関係が認めら れ，換算係数として $18.2 \mathrm{mgC} / \mathrm{mg} \cdot \mathrm{chl} . \mathrm{a}$ という值 が得られた。 この值を用いて Fig.4-E および F の実 験の粕形成に伴う澡類の付着物中に占める割合の変化 を計算した，その結果を Fig．７亿示す．との結果，

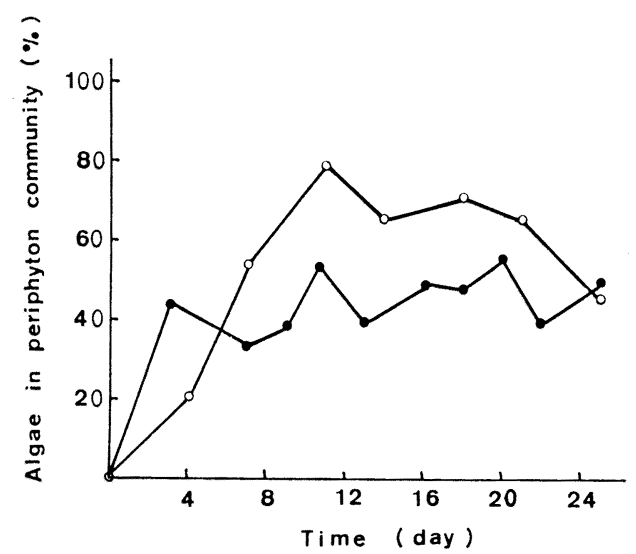

Fig. 7. Changes in algal contents in the periphyton community in terms of organic carbon attendant on the film development. Symbols: - - , May 1973; Jul. 1973.

炭素量では香季に最高時で, 付着微生物中の約 $80 \%$ を 澡類が占め，その他の時でも約 50 70\% を占めてい ることが分かった。 また，夏季には，付着微生物中に 占める藻類の割合は最高值で $55 \%$ ，通常は 40 55 \%と春季に比べるとかなり低い值になった，しかし， ての場合は，換算係数を春季と同じ值を用いているの で，過少に評佃している可能性が高い。

\section{C. 細菌量}

Fig. 8 に付着微生物膜形成に伴う細菌数の変化を 示す．全従属栄養細菌数はクロロフィルがほとんど検 出されない層形成初期で $2.4 \times 10^{7} \mathrm{cells} / \mathrm{cm}^{2}$ であっ た. この值は湖沼や河川水中の值と此較すると極めて 高い值であり，付着微生物膜の形成初期における細菌

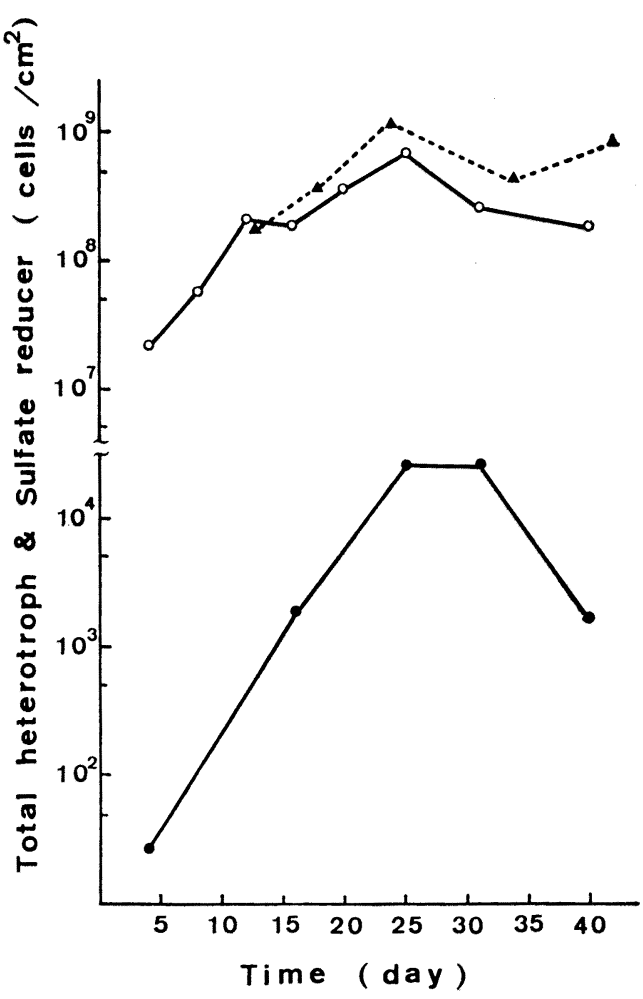

Fig. 8. Changes in numbers of aerobic heterotrophic bacteria and sulfate-reducing bacteria in periphyton community attendant on the film development. Symb-

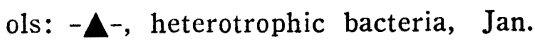
1973; -O-, heterotropic bacteria, Apr. 1974; -O-, sulfate-reducing bacteria, Apr. 1974.

類の役割の大きさを予想させた．冬季と春季を比較す ると現存量の変化の様子は類似していたが，冬季の方 が厚い膜が形成された後で高い細菌数を示した，最高 值は产季で $7 \times 10^{8} \mathrm{cells} / \mathrm{cm}^{2}$, 冬季で $1.2 \times 10^{9} \mathrm{cells} /$ $\mathrm{cm}^{2}$ であった. Table 1 に各季節における細菌数を 単位面積当りと単位炭素量当りで示した。単位面積 $\left(\mathrm{cm}^{2}\right)$ 当りでは $10^{7} \sim 10^{9}$ の間を, 単位炭素量 $(\mathrm{g})$ 当りでは $10^{10} \sim 10^{12}$ の間を変化していた。

Fig. 8 には絶刘嫌気性細菌である硫酸塩還元細 菌 数の変化も示したが，厚い付着膜が形成された段陼で は $2.4 \times 10^{4} \mathrm{cells} / \mathrm{cm}^{2}$ という非常に多い硫酸塩還 元 細菌が存在していた。 このととは, 微生物膜内部のか なりの部分が嫌気的条件にあるてとを示している。

\section{3. 光合成活性の変化}

層形成に伴う付着性藻類の一次生産の変化を Fig. 9 
Table 1. Number of aerobic heterotrophic bacteria in periphyton community grown on artificial substrata in several seasons.

\begin{tabular}{cccc}
\hline Sampling time & \multicolumn{2}{c}{$\begin{array}{c}\text { Submerged period of } \\
\text { substrata (days) }\end{array}$} & \multicolumn{2}{c}{\begin{tabular}{c} 
Number of heterotrophic bacteria \\
\cline { 3 - 4 }
\end{tabular}} & 15 & $2.4 \times 10^{8}$ & $3.4 \times 10^{11}$ \\
\hline Mar. 1972 & 5 & $6.8 \times 10^{7}$ & $1.1 \times 10^{11}$ \\
Aug. 1972 & 9 & $1.4 \times 10^{8}$ & $2.7 \times 10^{11}$ \\
Oct. 1972 & 18 & $3.8 \times 10^{8}$ & $7.9 \times 10^{11}$ \\
Feb. 1973 & 24 & $1.2 \times 10^{9}$ & $1.1 \times 10^{12}$ \\
Feb. 1973 & 12 & $2.0 \times 10^{8}$ & $2.5 \times 10^{11}$ \\
May 1974 & 25 & $7.0 \times 10^{8}$ & $6.2 \times 10^{11}$ \\
May 1974 & & & \\
\hline
\end{tabular}

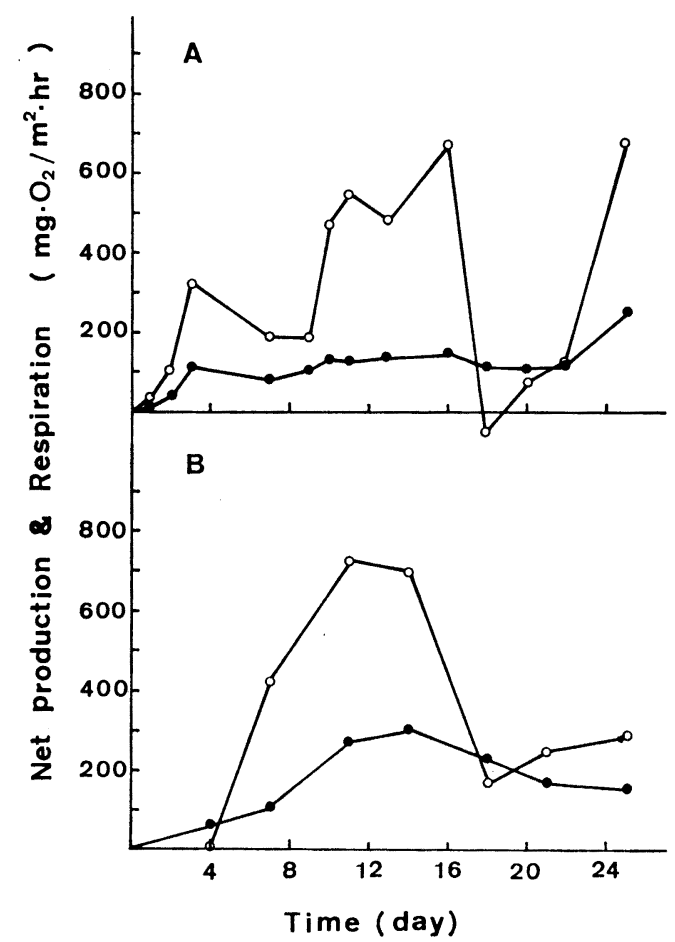

Fig. 9. Changes in photosynthetic rate (net production) and respiration rate of periphyton community attendant on the film development. Photosynthetic rates were determined at about 20,000 lux and in situ water temperature without scrapping off the periphyton from the substrata. A, Jul. 1973; B, May 1973. Symbols: $-\bigcirc-$, photosynthetic rate (net production) ;--, community respiration rate.

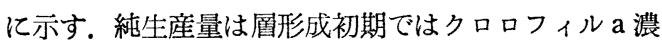
度 (Fig. 4-F, E) とよく対応した変化を示した. 最高 值は春季でも夏季でもあまり変わらず約 $700 \mathrm{mg} \cdot \mathrm{O}_{2} /$

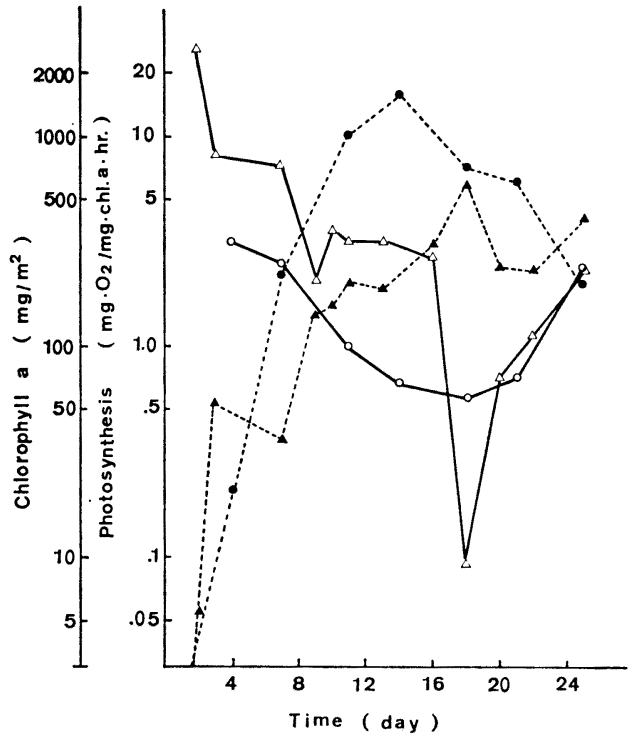

Fig. 10. Changes in chlorophyll amount and photosynthetic rate (Pgmax) of periphyton community attendant on the film development. Photosynthetic rates were determined at about 20,000 lux and in situ water temperature without scrapping off the periphyton from the substrata. Symbols: - chlorophyll in May 1973; - $\bigcirc-$, photosynthetic rate in May 1973; - $\mathbf{-}-$, chlorophyll in July 1973; $-\triangle-$, photosynthetic rate in July 1973.

$\mathrm{m}^{2} . \mathrm{hr}$ であった. 一方, 呼吸量は純生産量に比べる と比較的変化が少なく夏季では約 $100 \mathrm{mg} \cdot \mathrm{O}_{2} / \mathrm{m}^{2} . \mathrm{hr}$, 春季では $100 \sim 300 \mathrm{mg} \cdot \mathrm{O}_{2} / \mathrm{m}^{2} . \mathrm{hr}$ の間を変動した. 呼吸量が春季に高かったのは, 藻類の現存量が高く, 河川水との接触面積が大きかったためと思われる，純 生産量は最高值に達した後急激に減少した。 これは付 
着物の剥離によるものではない，澡類の現存量は非常 に高いにもかかわらず生産量のみ減少したものである。 ての関係を更に詳細に検討してみた，Fig. 10 は単 位クロロフィル当りの総生産量とクロロフィル a 濃度 の層形成に伴う変化を示したものである．光合成量は 付着初期で $3 \sim 20 \mathrm{mgO}_{2} / \mathrm{mg} \cdot \mathrm{chl} . \mathrm{a} \cdot \mathrm{hr}$ とかなり高 い值を示したが，付着膜が厚くなるに従って低下し

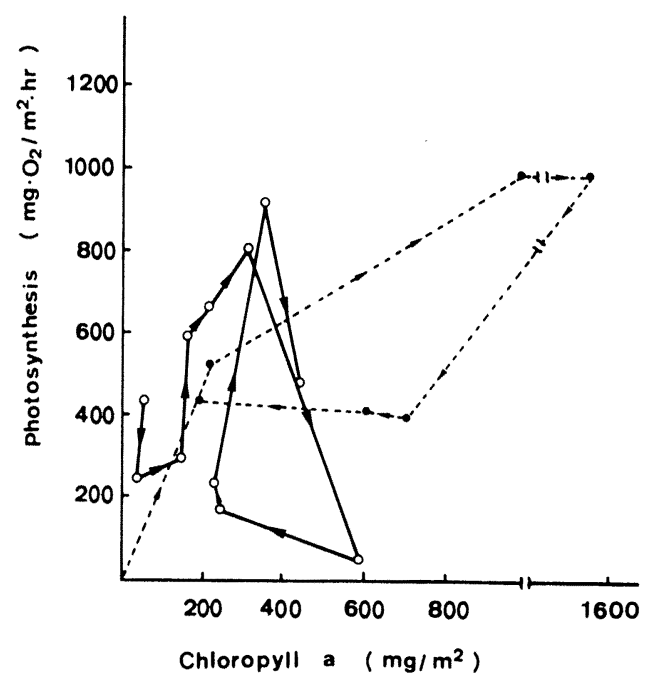

Fig. 11. Relationship between chlorophyll-a and photosynthetic rate $(\mathrm{Pg} \max )$ of algae. The plots were joined with lines in the order of substrata sampling. Dotted line, May 1973; solid line, July to September 1973.

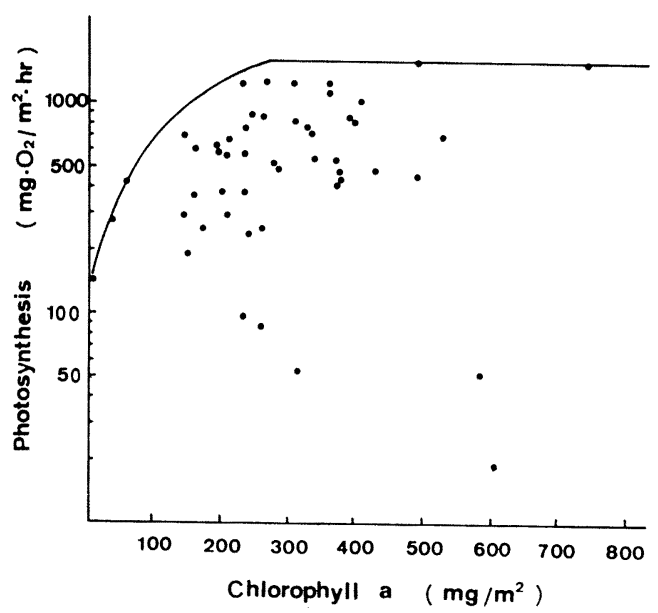

Fig. 12. Relationship between chlorophyll-a and photosynthetic rate of sessile algae at water temperature of $25-30^{\circ} \mathrm{C}$ and light intensity of $20,000-23,000$ lux.

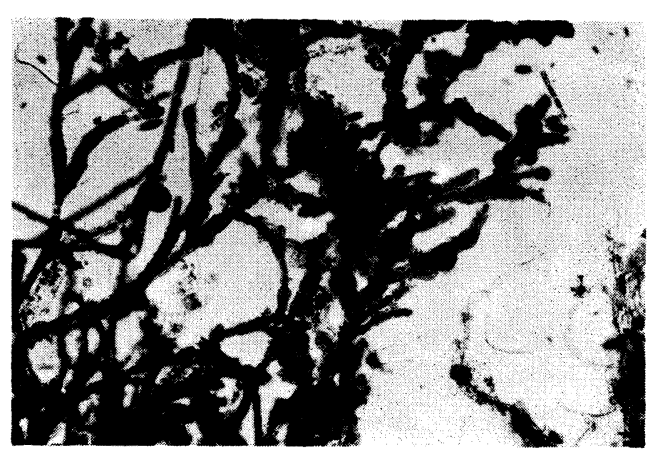

Fig. 13. Last stage of the periphyton development in the midstream of the River Tamagawa. A large number of bacteria adhered to the Stigeoclonium sp. The slide was submerged for 42 days in river water in spring. $(\times 100)$.

$1 \sim 3 \mathrm{mg} \cdot \mathrm{O}_{2} / \mathrm{mg}$. chl. a $\cdot \mathrm{hr}$ 程度になった。 特に, 付 着物が剝離する直前は急激な低下を示し， $0.1 〜 0.6$ $\mathrm{mgO}_{2} / \mathrm{mg}$. chl. a·hr という非常に低い值となった. 付着物の剥離後は再び上昇し，急激な低下を示す前の レベルまで回復した。

Fig. 11 は藻類現存量と生産量の関係を示すが, この図から現存量と生産量の間には以下のような 3 段 階の関係が兒られることがわかった，第 1 は現存量の 増加とともに生産量も増加する期間, 第 2 は生産量は 一定もしくは著しく減少するが，現存量はなお増加す る期間, 第 3 は生産量はかなり低い值で一定し, 現存 量が著しく減少する期間である。

第 1 の期間は最も理解しやすいが，第 2 の期間は付 清物が凰構造をとることによって層内部への光の供給 が抑えられ, 有光首中の藻類量が一定になるために生 産量も一定になるものと考えられる。Fig. 12 にク ロロフィル $\mathrm{a}$ 濃度と光合成量との関係を示すが， ク口 ロフィルa量が約 $250 \mathrm{mg} / \mathrm{m}^{2}$ に増加しても生産量は約 $1,100 \mathrm{mgO}_{2} / \mathrm{m}^{2} . \mathrm{hr}$ 以上の值にはならなかった。 ま た, 現存量が槀くなると生産量が著しく低下すること が多くなった。とのような現存量の高い時の生産量の 減少の原无としては, 其存する細菌類などの影響によ る澡類の活性の低トが考えられた，Fig. 13 に剥離す る直前の付着物中の Stigeoclonium sp. を示すが, 藻体の表面にびっしりと細菌が付着している様子がわ かる。乙のような現象は付着物の剝離直前にはしばし ば観祭された，第 3 の期間は付着物が剥離してゆく 期間であるが，クロロフィルa量が約 $200 \mathrm{mg} / \mathrm{m}^{2}$ まで 減少すると生産量も現存量も再び増加し始める傾向を 
示した. この値は Fig. 12 の生産量が一定になるク ロロフィルa量とよく一致している。乙のととから， クロロフィル量が $200 \mathrm{mg} / \mathrm{m}^{2}$ まで減少すると付着 膜の下層まで光が到達するようになり，下首での光合 成によって層内部が好気的になるため, 付着力が回復 するものと考えられる。以上のととは，嫌気性の硫酸 塩還元細菌が付着物の豩離によって, 全従属栄養細菌 もより急激に減少していることからも裏付けられる (Fig. 8).

\section{4. 考察}

付着微生物膜の形成過程の顕微鏡的観察や現存量の 変化に関しては河川を始め湖沼や海洋および散水沪床 等についてかなり多くの研究がある（MADSEN, 1972； MACK et al., 1975; 坂本, 1976; JORDAN and STALEY，1976). 付着微生物膜中には生産者である藻 類の他消費者, 分解者である原生動物, 細菌類等も含 まれている，乙のような微生物の組成は環境条件の変 化によって当然変わるものと考えられる. 従属栄盖生 物である細菌類の量は基質である有機物の供給量によ って決まる。

湖沼のように有機物が主として藻類の一次生産から 供給される場合には, 細菌量は藻類量によって決めら れる、桜井（1975）は富栄養化の進んだ諏訪湖におい て藻類量に対する細菌量を 5 〜 $15 \%$ と報告している. 一方, 河川においては有機物の供給源として, 藻類に よる光合成生産の他に陸上からの供給が考えられる. 特に都市近郊の河川では都市廃水中に多量の有機物が 含まれている場合が多く，大きな有機物の供給源とな っている.

多摩川もこの例外でなく実験地点の河川水中に BOD 值で, 冬季で $15 \sim 32 \mathrm{mg} / l$, 夏季で $5 \sim 10 \mathrm{mg} / l$ という多量の有機物が含まれていた（AIZAKI，1978）. そのため, スライドグラスや塩化ビニール板等の人工 基層を河川水中へ沈めた場合, しばらくの間は細菌類 が付着微生物群集のほとんどを占めてしまう。このこ とは，今回の顕微鏡観察からも明らかであるし，有機 物の多い散水沪床の付着物でも同様な結果 (MACK et al., 1975） が報告されている. このように付着微生 物膜形成過程の初期において細菌が優占するのは, 增 殖速度が藻類に比べてかなり早い（AIZAKI，1979）乙 とと，増殖に必要な有機物を藻類に依存しなくてもよ いためと考えられる。

しかし，JORDAN and STALEy (1978) によれば污 濁河川に比べて有機物濃度がかなり低い湖沼において
も，基層を浸漬した埸合には初めに細菌類が增殖する。 ZoBeLL （1943）は固体表面が有機物を濃縮する機能 をもつため, 細菌類の増殖に適した環境になると報告 している，乙れらを考え合わせると，付着微生物膜の 発達段階の初期では細菌類が付着膜形成に主たる役割 を果たすものと若えられる。

付着微生物膜の形成に伴って澡類量が増加し, 多い 時にはその約 $80 \%$ 占めているてとが今回の研究で明 らかになった。しかし，ての付着物中の藻類量も河川 水中の有機物濃度に応じて変化することが尔想される。 すなわち, 外部からの有機物供給の多い所では従属栄 養生物が多くなり，藻類量は低下するものと考えられ る。このととは, 多摩川の上流部や下水路化した都内 の河川での調查（相崎, 未発表）からも推測される. この調査では, 付着物炭素量に対するクロロフィルa 量の比（，）は多摩川の上流部では 0.8〜1.7 \% であ ったが, 中流部では2.2〜2.5\%, 都内の下水路化し た河川では 0.2〜0.4官であった. このととは, 河 川の水買によって付着物中の藻類と従属栄養微生物の 比が変化するととを示すものである，したがって，同 一地点でも水質の変化に応じてての比か変わることが 予想される。

今回の調查でも水質の琹化する夏季や冬季には付着 物中に上める藻類量が低下していた。しかし，クロロ フィル量を藻類量に換算する方法は藻体中のクロロフ ィル含量が季節や栄養状態等により変化するので, 一定の換算係数を各季節を通じて使用することには無 理がある. Persons et al. (1961) や DARLEy (1977) によれば培養した藻類の炭素量と chl. a 量の比は 19 から 100 程度の值をとっており，特に，栄養が豊富な 場合には $22 \sim 26$ 程度の值を示している。これらの值 に比べると, 今回得られた $18.2 \mathrm{mg} \cdot \mathrm{C} / \mathrm{mg} \cdot \mathrm{chl} . \mathrm{a}$ と いう値は若干低い、しかし，春季で, 新鮮な栄養塩が 常に供給される流水条件であることを考虑すれば， この時期の值としては妥当なものと考えられる.

本研究では，ての值をそのまま夏季にも適用したが， 夏季には藻類炭素量とクロロフィル a 量の比はもっと 高くなると予想される。また，層形成の初期と後期で も換算係数を変える必要があるかもしれない，今後， これらの面で，更に検討する必要がある。これとは 别に全菌数汃ら細菌量を推定する方法もある。桜井 （1975）によれば細菌の 1 紏胞は約 $0.025 \times 10^{-12} \mathrm{~g} の$ 炭素量に相当する。 TEzUKa et al. (1974) によれば 多摩川の調查地点付近の付着物中の全菌数と生菌数の 比は約10倍である。これらの值を使用して Table 1 
に示した細菌量の付着物中に占める割合を求めると約 5 28 \% になった. 今回の研究では全菌数の測定は 行なわなかったが，今後てのような面からの解析も必 要と思われる。

河川での一次生産の研究は OduM (1965) や McConNell and Sigler (1959) 等の研究以来かなり 行われてきた（WETZEL, 1975; AIzAKI, 1978).しか し, 圈形成との関連でとらえた研究は筆者の知る限り ではない，湖沼や海洋における一次生産の測定の場合， 生産量の深さが問題になる. 付着藻類の場合も同椂に 生産量の厚さを知る必要がある. しかし, 湖粱等の場 合と違って付着物の種々の厚さの照度を測定するこ とは非常に困難である。 Tominaga and Ichimura （1966）はスライドグラスに藻類を付着させ，透過光 が表面光の $1 \%$ の值になった時のクロロフィル a 量 を測定し，生産㟄中の藻類量を推定している。彼らの 実験では約 $200 \mathrm{mg} / \mathrm{m}^{2}$ が生産層中のクロロフィル a 量であった. 有賀（1973）はいろいろな水域の生産㐿 中のクロロフィル a 量をまとめているが，それによ ると富栄養湖で $100 \sim 290 \mathrm{mg} / \mathrm{m}^{2}$, 培養した藻類で最 高 $900 \mathrm{mg} / \mathrm{m}^{2}$ と見積もっている. 今回の実験では付 着物中のクロロフィル a 量が約 $250 \mathrm{mg} / \mathrm{m}^{2}$ を越えて も, 生産量は一定の值より増加しなかった。 このてと は, 多摩川の付着物においても生産層中のクロロフィ ル a 量がおおよそ $250 \mathrm{mg} / \mathrm{m}^{2}$ 程度であるととを示し ている. ての值は, 他の水域での值と非常に近似して おり, 水界での生産構造を知るうえで興味のある結果 である。

植物プランクトンの光合成速度を比較する場合, 光 飽和条件下での光合成速度 (Pg max) が重要である. 有賀（1973）によれば各種水域での Pgmax は唄栄養 湖で 0.1 1 mgC/mg・chl. a $\cdot \mathrm{hr}$, 中栄養湖で 1 3 mg $\mathrm{C} / \mathrm{mg} \cdot \mathrm{chl} . \mathrm{a} \cdot \mathrm{hr}$, 富栄養湖で $2 \sim 6 \mathrm{mgC} / \mathrm{mg} \cdot \mathrm{chl} . \mathrm{a}$ $\cdot \mathrm{hr}$ である。今回の実験では, 浸漬初期の付着膜があ まり厚くない段階では，炭素量に換算 $\left(\mathrm{O}_{2} \times 1 / 2.67\right)$ して, $1.1 \sim 7.5 \mathrm{mgC} / \mathrm{mg} \cdot \mathrm{chl} . \mathrm{a} \cdot \mathrm{hr}$ と富栄養湖に匹 敵もしくはそれ以上の速度であったのに対し, 付着膜 が厚くなると 0.4〜 1. $1 \mathrm{mgC} / \mathrm{mg} \cdot \mathrm{chl} . \mathrm{a} \cdot \mathrm{hr}$ と貧栄養 湖の值に近くなった. 更に付着物が剥離する直前では $0.04 \sim 0.3 \mathrm{mgC} / \mathrm{mg} \cdot \mathrm{chl} . \mathrm{a} \cdot \mathrm{hr}$ と極めて低い值を示し た.このととは, 付着藻類が層形成初期には河川水中 の豊富な栄養塩類を利用して高い生産速度を示すが， 㐿形成の進行に伴って付着膜内部一の光の透過が制限 され付着膜中の澡類の平均光合成速度は低下するて とを示している。しかし，付着物の剥離直前に見られ
る著しい光合成速度の低下はこのような理由では説明 できない。とのような現象は層内部の従属栄養的な分 解過程での細菌類の作用や代謝産物による阻害等の複 雑な要素が関係すると考元られ, 今後更に詳しく検討 する必要がある。

\section{摘 要}

典型的な富栄養河川である多摩川中流部で付着微生 物膜発達過程の観察を浸漬したスライドグラスおよび 塩化ビニール板を用いて行ない, その間の現存量およ び光合成速度の変化を調べた。 その結果, 以下のとと が明らかになった。

1）付着膜の形成は細菌類によって始められ，ある 程度の細菌膜形成後に藻類, 原生動物類が増殖を開始 し，最終的には藻類が優占した。

2）付着物の増加曲線は季節変化を示したが, 最高 值は $80 \sim 130 \mathrm{~g}$ dry wt. $/ \mathrm{m}^{2}$ 程度のととが多かった。 付着物中の有機物量は約 30〜 40\%であった。

3）基層を河川水に浸漬した後藻類が急激に増殖し 始めるまでの期間の長さは水温と高い相関を示した. クロロフィルa量の最高值は約 400 500 mg chl. a $/ \mathrm{m}^{2}$ のととが多かった。

4）春季における付着物中の藻類量は全有機物量の 最高值で約 $80 \%$, 通常 50〜70\%であった。

5）付着物中の全從属栄養細菌数は $10^{7} \sim 10^{9} \mathrm{cells} /$ $\mathrm{cm}^{2}, \quad 10^{10} \sim 10^{12} \mathrm{cells} / \mathrm{gC}$ 程度のととが多かった. ま た, 付着膜発達過程の初期にも多量の細菌が存在した. 厚い付着膜形成後には多量の硫酸塩還元細菌が検出さ れ，風内部がかなり嫌気的であるととを示した。

6）光合成速度は付着膜の発達とともに大きく変化 し, 春季わよび夏季で, 膜形成初期では $3 \sim 20 \mathrm{mgO}_{2}$ /mg・chl.a.hr であったのが, 膜形成にともなって $1 \sim 3 \mathrm{mgO}_{2} / \mathrm{mg} \cdot \mathrm{chl}$. a h hr まで低下した. 特に付着物 が剥離する直前には $0.1 \sim 0.6 \mathrm{mgO}_{2} / \mathrm{mg} \cdot \mathrm{chl} . \mathrm{a} \cdot \mathrm{hr}$ という非常に低い值となった。

7）藻類現存量と光合成速度の間には膜の発達にと もなって以下のような 3 段階の関係がみられた。

(1) 現存量も生産量も增加する期間, (2) 生産量は一 定もしくは著しく減少するが，現存量は増加する期間， (3) 生産量はかなり低い值で一定し, 現存量が著しく 減少する期間.

\section{交献}

Aizaki, M. (1978) : Seasonal changes in standing crop and production of periphyton in the 
Tamagawa River. Jap. J. Ecol., 28: 123134.

Aizaki, M. (1979): Growth rates of microorganisms in a periphyton community. Jap. J. Limnol., 40: 10-19.

有賀祐勝（1973）：水界植物群落の物質生産 II 一植 物プランクトン。共立出版社.

Darley, W. M. (1977) : Biochemical composition. p. 198-223. In: D. Werner (ed), The Biology of Diatoms. Blackwell Scientific Publications, Oxford.

Jordan, T. L. and J. T. Staley (1976) : Electron microscopic study of succession in the periphyton community of Lake Washington. Microbial Ecol., 2: 241-251.

古井戸良雄・土屋隆夫（1970）：多摩川の水質污濁の 現状と対策. 用水と廃水, 12: 40-44.

河合 章 (1969)：硫黄化合物の代謝に関与する紲菌 群の計数法. p. 295-300. 陸水生物生産研究法. 講談社.

McConnell, W. J. and W. F. Sigler (1959): Chlorophyll and productivity in a mountain river. Limnol. Oceanogr., 4: 335-351.

Mack, W. N., J. P. Mack and A. O, Ackerson (1975) : Microbial film development in a trickling filter. Microbial Ecol., 2: 215-226.

Madesen, B. L. (1972): Detritus on stones in small streams. In: U. Melchiorri-Santolini and J. W. Hopton (ed), Detritus and its role in Aquatic Ecosystems. Mem. Ist. Ital. Idrobiol., 29 suppl. 385-403.

Odum, H. T. (1956): Primary production in flowing waters. Limnol. Oceanogr., 1: 102117.

Parsons, T. R., K. Stephens and J. D. H. StriCKLAND (1961): On the chemical composition of eleven species of marine phytoplankters. J. Fish. Res. Bd. Canada. 18: 1001-1016. 桜井善雄 (1967)：水中の一般紐菌数検定法に関する 2,3 の検討. 日本水处理生物学会誌, 2: 2127.
桜井善雄（1975）：湖沼における細菌と藻類の量的関 係. p. 35-51. 微生物の生態 2 , 東宗大学出版 会.

坂本 充 (1976)：生態遷移II. 其立出版社.

Steele, L. H. and I. E. Baird (1962) : Carbonchlorophyll relations in cultures. Limnol. Oceanogr., 7: 101-102.

Steele, L. H. and I. E. Baire (1965) : The chlorophyll-a content of particulate organic matter in the northern north sea. Limnol. Oceanogr., 10: 261-267.

Tezuka, Y, Y. Watanabe, H. Hayashi, S. Fukunaga and M. Aizaki (1974): Changes in the standing crop of sessile microbes caused by organic pollution of the Tamagawa River. Jap. J. Ecol., 24: 43-49.

Tominaga, H. and S. Ichimura (1966): Ecological studies of the organic matter production in a mountain river ecosystem. Bot. Mag. Tokyo, 79: 815-829.

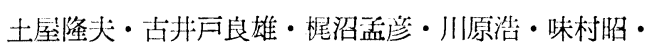
田辺孝・橫甶章・牧野厷（1970）：多摩川の総合 調查結果汸て。用水と廃水, 12: 1094-1108. Wetzel, R. G. (1975) : Primary production. P. 230-247. In: B. A. Whitron (ed), River Ecology. Univ. California Press, Berkeley and Loa Angeles.

ZoBell, C. E. (1943) : The effect of solid surfaces upon bacterial activity. J. Bacteriol., $46: 39-56$.

（著者：相崎守弘，東宗都点大学理学部，東宗都世男 田谷区深沚； Morihiro AIzAKI, Department of Biology, Faculty of Science, Tokyo Metropolitan University, Setagaya-ku, Tokyo. 現住所: 国立公 害研究所水質土燷環境部, 荻城県筑波郡谷田部町; Present address: Water and Soil Division, The National Institute for Environmental Studies, P. O. Yatabe, Ibaraki 305). 1980 年 4 月 25 日 受理 